\title{
EchoGéo
}

$48 \mid 2019$

Illegal cannabis cultivation in the world

\section{Living Dangerously: Confronting Insecurity, Navigating Risk, and Negotiating Livelihoods in the Hidden Economy of Congo's Cannabis Trade}

\section{Ann Laudati}

\section{CpenEdition}

\section{Journals}

Electronic version

URL: https://journals.openedition.org/echogeo/17676

DOI: 10.4000/echogeo.17676

ISSN: 1963-1197

Publisher

Pôle de recherche pour l'organisation et la diffusion de l'information géographique (CNRS UMR 8586)

Electronic reference

Ann Laudati, "Living Dangerously: Confronting Insecurity, Navigating Risk, and Negotiating Livelihoods in the Hidden Economy of Congo's Cannabis Trade", EchoGéo [Online], 48 | 2019, Online since 13 July 2019, connection on 31 July 2021. URL: http://journals.openedition.org/echogeo/17676 ; DOI: https:// doi.org/10.4000/echogeo.17676

This text was automatically generated on 31 July 2021.

EchoGéo est mis à disposition selon les termes de la licence Creative Commons Attribution - Pas d'Utilisation Commerciale - Pas de Modification 4.0 International (CC BY-NC-ND) 


\title{
Living Dangerously: Confronting Insecurity, Navigating Risk, and Negotiating Livelihoods in the Hidden Economy of Congo's Cannabis Trade
}

\author{
Ann Laudati
}

\section{Introduction}

A middle-aged Congolese man stands in front of one of several of his shambas ${ }^{1}$ located deep in the Moyens Plateaux of the DRC's South Kivu Province. Vibrant green foliage largely dominated by a single plant species, surrounds and almost overwhelms the slight stature of the man. The man holds a wad of cash, intentionally fanned out to the viewer as evidence of the financial benefits the farmer reaps from the production of the crop he currently stands in front of, a calculated answer to a researcher's question, "what meaning does the cannabis plant hold for your household?". Despite the country's well-reputed resource wealth, existing narratives surrounding the Democratic Republic of the Congo's rich natural resource base have largely attended to its mineral wealth and particularly the link between certain minerals, notably coltan and gold, and the violence in the region. The reality of which and how natural resources matter in the Congo, however, is increasingly understood by scholars as much more varied and complex and requires moving beyond just minerals (Laudati, 2013). During two consecutive summer field visits in 2017 and again in 2018, farmers from different villages across South Kivu were given a disposable camera and instructions to photograph their engagement in the production of cannabis. Aside from an unsurprising stock of personal family photographs, accidental shots, and a steady supply of the marijuana plant itself, each farmer took care to set marijuana as the literal and figurative backdrop of their individual and collective family wealth. In so 
doing, these farmers subsequently set the scene for the focus of this paper, and set in motion a direct challenge to the narrative of violence, delinquency, and greed that currently foregrounds most discussions of the cannabis economy in Africa. Yet the surreptitious nature of the photo's subject and geography, reveals yet another critical aspect of the cannabis economy. Underlying the photos exhibition of profit lies a more complicated story of risk, danger, and insecurity, not as it has previously been understood, but as it shapes the everyday lives of Congolese people.

The Democratic Republic of Congo is allegedly one of, if not the most, significant producers of the plant, Cannabis sativa ${ }^{2}$ (CIA, 2013; INCB, 2012), across the African continent today. For many farmers, marijuana serves as the most important crop for their individual and household's well-being. As one informant ${ }^{3}$ noted illustratively, "cannabis is the cassava of [South Kivu]". The fact that the DRC is the largest producer of cassava in Africa after Nigeria and that cassava serves as the staple food and income for 70 percent of the Congolese population (Muengula-Manyi et al., 2012) demonstrates the high importance credited to the drug. In some cannabis producing areas visited during fieldwork close to $90 \%$ of households, or as one village chief suggested, "everyone except the priests", rely on income from the trade either as a grower, a trader, or a transporter. Yet, despite substantive cultivation of the drug in parts of the country, the trade has failed to garner much attention, particularly regarding its significance for local production systems or as a potentially valuable market commodity.

Findings draw from over sixteen months of qualitative fieldwork by the author in South and North Kivu since 2011 interviewing a range of actors involved in the production and trade of the plant from growers to sellers to consumers, as well as government officials and state actors, local NGO and international organization staff, including UN workers. Data was gathered from nearly twenty different villages and urban centers across the two eastern provinces and from conversations with civilians as well as army and armed group personnel and reflects a diversity of perspectives across gender, ethnicity and socio-economic status.

Drawing on the narrated experiences of those involved in the production and trade of the drug, this paper contributes to a growing literature on the hidden economies of the trade in marijuana. By focusing on the experiences of those engaged in the trade, this paper first seeks to challenge the uncritical muddling of cannabis as an illegal and therefore illegitimate economy (see Abraham and van Schendel, 2005), and bring its oft-ignored linkages to rural African livelihoods, and in particular, its importance as a key strategy within a diversified household economy (Bloomer, 2009) from 'out of the shadows' (Laudati, 2014). While still maintaining livelihoods as a theoretical anchor, the paper turns toward understanding these livelihood struggles within the context of Congo's contemporary warscape and explores how the current trade shapes and is shaped by the region's continuing insecurity. In doing so, this paper challenges mainstream narratives that have narrowed the story of the contemporary cannabis trade in the region within the confines of violence and criminality ${ }^{4}$. Building from recent work that upsets conventional framing that considers violence as complementary to and thus naturalized within the workings of the cannabis economy (Suckling, 2016), this paper seeks to further reframe the cannabis trade as a response to Congo's landscape of violence rather than a symptom of it. In particular, it presents 
evidence of how the plant's illegality and the extra-legal networks its illegality engenders is shaping the terms of the trade itself.

The paper begins with a discussion of the various uses of the plant for individual and household consumption. Starting with a brief reference to its pre-colonial use and continuing up through the present, this section illuminates the multiple uses and meanings of the plant by local Congolese. The following section explains the rise of cannabis as an illegal substance and how its colonial era demarcation as a dangerous plant remains, albeit updated and dressed in a modern day framing. The remainder of the paper settles into an examination of the various ways in which engagement in the trade engenders new strategies for navigating risk and danger within Congo's wider landscape of insecurity. In so doing, it seeks to confront how we understand we understand the very terms of risk and insecurity as played out in the day-to-day lives of those who navigate through the hidden economy of Congo's cannabis trade.

\section{Consuming Cannabis}

The story of cannabis consumption and use in the Congo is rooted in a long if indefinite history. While impossible to date the emergence of cannabis in the country with any precise accuracy, by the $17^{\text {th }}$ or $18^{\text {th }}$ century, the consumption of cannabis was widely accepted by the local population (Fabian, 2000), and archival research suggests the existence of, "a thriving industry (Hunt, 2016, p. 69)" at the time of Belgium arrival in the region. For these earlier communities, cannabis consumption was often interwoven within ritualistic purposes, as illustrated by the Baluba or Bashilenge ${ }^{5}$ of Central Congo, the most recognized of the cannabis smoking cults popular during the mid-nineteenth century. More contemporary accounts of cannabis use throughout the region demonstrate that the tradition of ritual cannabis consumption continues even today. Cuvelier's work (2011) on present-day Katanganese Rastafarians, for example, presents perhaps the most in-depth account of a modern community of cannabis smokers whose red, green, and gold colored flags are brightly evident throughout the region including along the streets of South Kivu Province's capital city, Bukavu. Apart from the drug's connection to the Rastafarian movement and rare anecdotal reports of a possible link to the magic incorporated into Mai Mai warfare practices, present day cannabis consumption appears less often aligned with ritualistic or even recreational settings than with a vast array of pharmacological as well as functional uses linked to everyday life.

Present-day cannabis consumption typically serves two main functions - as a readily available and alternative provider of medicine and as a mechanism to cope with day-today occupational hardships and risks. Ethno-botanical studies conducted from 1975 onwards in the DRC, for example, note the plant's use as a relief for childhood illnesses such as asthma, chicken pox and measles, and as veterinary medicine (Bokdam and Droogers, 1975; Disengomoka and Delaveau, 1983; Baerts and Lehmann, 1989 and 1991; Kasonia, 1993; Kalanda and Bolamba, 1994; Byavu et. al., 2000; Balagizi et. al., 2005). Such studies however are far from exhaustive. Evidence from fieldwork suggests that the plant serves an even wider range of uses. Interviewees noted the use of the plant to treat a variety of ailments from cough to ear mites, from snake bites to hernia, from skin disease to the plague, or mixed with salt as a remedy against livestock disease, and particularly for the treatment of traditional diseases such as kivubo ${ }^{6}$. Some households 
also reported using the ash of the plant for treating and healing wounds, and as a salve to assist with the cutting of the umbilical cord during birth. In most cases of household use, only the leaves or flowers of the plant are used, whereas traditional healers are known to incorporate other parts of the plant such as the stalk in the treatment of kifafa (epilepsy). Recent work by Roulette et al. (2016; see also Roulette and Hewlett, 2018) looking at the high prevalence of cannabis consumption among the Aka forestforager group suggests it serves as a self-medication against helminths (intestinal worms). Equally important, cannabis's ability to provide stamina and 'courage on the job' was widely cited by study participants as the primary motivation for taking cannabis among Congolese men (see also Laniel, 2006; York, 2012). As a police officer in Sange noted, "Marijuana helps us not to fall asleep when we are patrolling. In addition, it gives us strength to face delinquent persons with whom we meet at night". A state military soldier in the Forces Armées de la République Démocratique du Congo (FARDC) adds, "In addition, when patrolling, we are always beaten by the cold, but when you have your hemp you will smoke it the whole night while patrolling and you will not feel cold". Writing in the mid-70s, Carl Sagan noted a similar usage among the Mbuti ethnic group that "helps to make the long waits... tolerable [in the] patient stalking and hunting of mammals and fish (1977, p.191 footnote)" - a finding similar to observations made by Hewlett (1977) of the Mbuti, as well as the Efe and Aka forest-forager groups. The same stamina-enduring properties cited by security agents and reported independently by Sagan (1977) and Hewlett (1977), have made the drug particularly popular among laborers such as artisanal miners who often endure horrific conditions and suffer long hours of difficult and dangerous work. As a captain from the Congolese army related, "from my experience [having been stationed] at Kasii, if you want to get someone to dig [for minerals], you have to give digging equipment as well as cannabis it's a provision, like nourriture (food)".

The drug presents a similar function within Congo's landscape of continuing violence as well. Among Congolese soldiers, for example, the consumption of cannabis serves as a mechanism to cope with the daily hardships of the job, hunger, and to reduce fear in combat (Eriksson-Baas and Stern, 2010). Additionally, the drug is frequently given to fighters from either side of the battlefield in order to stimulate their desire to fight or make them unaware of danger, or, after a battle, ease the pain of injury or extreme tension caused by confrontation, particularly in the case of hand-to-hand combat. Furthermore, the drug's relevance within the DRC's current landscape of insecurity is not limited to those directly engaged in the region's violence. For example, Babaembe cattle keepers of Fizi territory, where village raids by pillaging forces are common, testify to using the plant in order to protect their cattle through what is known locally as ijunguu - the disappearance - which reportedly makes cows invisible to potential looters. Thus, although early appreciations for the drug centered on its consumption and notably its "most voluptuous sensation" (Timbs, 1890, p. 231), its significance and use within modern Congolese society has since diversified and continues to be adapted in different ways to fit the changing context and realities of Congolese life, including its violent landscape.

\section{The Making of a Dangerous Plant}

Despite the drug's historical ties to the region, today the production, sale, and consumption of cannabis are regarded as criminal acts punishable by law. Following 
regulations accorded by The Hague Convention of 1912, cannabis laws in Congo were enacted in 1917 (INL, 2011) by the colonial tribunal, which put into law "repression of the cultivation, consumption, and sale of Indian cannabis" (Dembour, 2000, p. 86). As Duvall (2017) notes, cannabis-control laws, enacted with the stated aim of improving native health, preserving labor quality, and preventing crime (Williams and Warf, 2017), were in fact motivated in service of Europe's civilizing mission (controlling native labor and religious proselytizing) - of which African cannabis was considered a hindrance to. Based upon historical records of high imprisonment ratios during this time period, Bernault (2007) argues, the decree of the cultivation of cannabis along with a range of other acts by the French and Belgium Colonial governments as a punishable offense in 1910 was in fact a deliberate tactic to further the "criminalization of native life... through administrative and short-term sentences [which] thus provided tremendous leverage for taking hold of the colonised and for controlling local economies and native labour (p. 63)". While the use of these indigénats coincided with wider political-economic issues, namely the tax demands already placed on African populations, a concurrent subsistence crises and the slow increase in monetary circulation that made fines unrealistic sentences, they nevertheless were part of an "intense policy of taming... resistance to white domination" (p. 66). The use, cultivation, and trade of cannabis, as argued by Nancy Rose Hunt (2016), was deliberately singled out because it signalled defiance on behalf of the native population. As she describes, cannabis diverted attention away from the preferred colonial task of copal production, which was linked to the colonial monies needed to pay taxes. Stated otherwise by a local chief at the time, many did not want to collect copal because hemp offered them another lucrative resource. In response, the colonial administration ordered military campaigns to uproot cannabis plants, which were seen as a threat to colonial economic interests. "The plant", she contends, "was like a currency with commercial sway, while its many powers made it a symbol and fact of dissent" (p. 70). By 1940, campaigns against cannabis drug use had pushed human engagement with the drug almost entirely underground (Duvall, 2017). The role of cannabis does not feature prominently in the country's historical record again until the period of independence ${ }^{7}$.

The laws regarding the sale, consumption and production of the plant, have remained the same since they were codified in 1917. Rather, arguably only the terms of how it has been constituted a dangerous plant has changed. Once seen as dangerous to the colonial project by presenting colonial subjects a path towards economic selfsufficiency, today it is seen as a resource that contributes to the region's violence in two central ways. Firstly, marijuana is seen as serving largely as a funding mechanism for rebel groups. This approach bases marijuana's importance to armed groups solely on the logic of extraction or harvesting for exchange. The ability of some armed groups, notably various Mai-Mai groups and more so, the Forces démocratiques de libération $d u$ Rwanda (FDLR), to profit from the trade was aptly expressed by a United Nations Joint Mission Analysis Centre (JMAC) officer stationed in Bukavu, "If you smoke marijuana, you support the FDLR".

A second approach centers on the psychophysiological effects of drugs on fighters and in particular how through the embodied practice of consuming the drug, the enabling of, particularly young, recruits to fight with and on behalf of armed groups, becomes possible. More recently, cannabis has been blamed for "diminish[ing] moral responsibility and increas[ing] violent tendencies" (ITUC, 2013), "thus...fuel[ing] much 
of the sexualized violence committed in the DRC" (Women Under Siege, 2012). In response to these discursive narratives that place marijuana alongside and partially culpable for the region's violence, insecurity, delinquency, and greed, NGOs, international bodies such as the AU and UN, as well as state agents continue to call for the drug's absolute abolition. Even regionally sourced media reports seem to be preoccupied with headlining seizures of the illegal substance ${ }^{9}$. Official statements, buoyed by sensationalist international NGO campaigns and regional media reporting, are further displayed through occasional anti-drug performances in which sacks of cannabis are publicly burned in Congo's largest cities, such as Goma and Bukavu - a strikingly familiar picture that harkens back to the piles of ivory burned under Kenyan President Moi's regime in the 1990s. It is no surprise then that many Congolese today view participants in the trade and their smoking beneficiaries as "delinquent" or "criminal." Yet conversations with local Congolese across the socio-political spectrum demonstrates that views of the drug's relationship to violence in the region are much more nuanced.

Community and civilian perspectives derive largely from one's involvement or lack of involvement with the trade. For example, Rastafarian groups, well-known smokers (if not occasional traders and growers themselves) of the drug present a sharp contrast to the views extended along official and international lines. As one Rastafarian chief related, "On the contrary, hemp contributes to security in the city in the way that we Rasta men are the ones who take care of the main road when there is a broken place that can cause damage to [vehicle] passengers. You will never hear a Rasta man fighting in such a such area for they are well-bred/instructed". Interestingly, this later claim refers to a series of free local trainings for Rastafarians conducted in his area "so that they might not misbehave towards others" - instituted in direct response to counter the "bad reputation and renown" that hemp smokers generally carry.

Yet even those involved in the trade who suggest that there may indeed be a link between the physiological effects of the drug and violence in the region, suggest that additional facts likely play a much more significant role. As nicely summed up by one informant, "the heads of people differ". "Rather", another informant explained, "the insecurity in the area is related to someone's interests. When someone wants to become a colonel in the army and he decides to go in the bush to start his own rebellion or militia, it is not the hemp which took him there, it is the interests he seeks in order to achieve his life goals".

More so, according to informants, it is alcohol that is more often associated with violence in the region than marijuana. Despite these assertions, involvement in the trade continues to carry a negative stigma - a mark that is both politically inscribed by actors at the national and international level as well as socially inscripted through local institutions.

As many interviewees related, views of the drug and some people's subsequent engagement in the trade, are shaped not only by observation and experience with drug-users but are additionally influenced by socio-cultural norms and beliefs. A grower relates how, "My wife does not help me in any work concerning [the growing or selling of cannabis]. From the growing season up to the time I sell it, I do all the work alone, as she considers this work as sinful for her Assemblies of God belief forbids her to get involved in illegal things". Adherence to different branches of Christianity was often cited as a barrier for some accessing the trade. In surely an ironic twist, one 
grower reported taking up smoking, "in order to forget all what happened to me in the church," following his excommunication - a direct result of the church authorities discovering his involvement in the trade. Given this broader socio-political milieu in which cannabis and its prohibition as a dangerous commodity is embedded, involvement in the trade is often seen as the result of "having no [other] choice" - a situation linked to the region's wider landscape of food insecurity and lack of alternative livelihoods.

\section{Working within a Landscape of (Food) Insecurity}

When asked about why individuals became involved in the trade, the majority of respondents set their answers against a backdrop of poverty, regional underdevelopment, and government neglect. Over the last 15 years, almost continual instability and a state of periodic violence have come to characterize the eastern region of the Congo, weakening the rural economy. Agricultural production, which serves as the primary economic activity for $80 \%$ of rural households, has decreased in the past decade (Vlassenroot et al., 2003) contributing to a cycle of food and nutritional insecurity (Kandala et al., 2011), low food production and subsequent extreme poverty (Rossi et al., 2006) while parts of the region, notably the landlocked Moyens and Hauts Plateaux, have grown increasingly isolated (ICRC, 2010). Limited access to land and markets, as well as post-war government neglect of the region have aggravated these conditions (van Acker, 2005; Ulimwengu et al., 2009; see also Ragasa and Ulimwengu, 2011). Thus while continuing insecurity in the region prevents many farmers from regularly accessing their farms to tender higher maintenance crops such as the water thirsty leaves of amaranth greens, known locally as lenga-lenga, retarded state agricultural programs have done little to alleviate reports of spreading diseases in the region's most important staple crops, cassava (cassava root rot) and bananas/plantains (banana wilt). As a result, more than $60 \%$ of the current population is labelled as food insecure (Walangululu et al., 2011) and more than $70 \%$ of farmers are categorized as poor (Dowiya et al., 2009). The continuing deprivation facing Congolese farmers and herders amidst these wider challenges, has led to, as Cox (2011, p. 247) argues, "diminishing returns of agrarian life". At the same time, these trends towards increasing rural poverty and decreasing food production, have coincided with reported increases in the illicit crop production of the drug - a likely outcome and adaptive response to the region's persistent insecurity and the reported growing numbers of the country's food insecure.

A study conducted in the late 1990s with support from the Kinshasan Association for the Prevention of Substance Abuse (LIPILDRO) noted even then an increase in local cannabis production. The average land area under cannabis cultivation reportedly increased from one to three hectares. In some areas, $60 \%$ of farmers had introduced cannabis into their production system (Labrousse, 2014). Indeed, households often grow cannabis in addition to traditional food crops and empirical data from interviews suggest that crop diseases and insecurity have played the leading role in lowering food security in the region. Multiple sources have presented little variation in retelling local experiences of insecurity such that, "in the past fifteen years, there were no diseases affecting food crops, but nowadays they are too many that reduce plant productivity, particularly the disease known as Mosiac for cassava and bananas", and "before when 
there were no plants diseases, we made money from those food crops but since the time the diseases came, we do not get money from those crops anymore and even to get food to eat has become a serious problem to us", "whereas", a third informant explains, "hemp has no disease". While few households grow cannabis almost exclusively, many rely on cannabis as a supplementary crop during periods when other major food staples, such as cassava, which take ten to twelve months to mature, are not ready to be harvested or whose harvests have declined. Cannabis thus provides the very 'cushion' against food crisis at the household level (see Laniel, 2006).

In addition to diminishing returns on agricultural and notably food crop production, many felt their engagement with the trade was further precipitated by the lack of alternative income-earning opportunities. Such statements parallel statistics gathered at the macro level, which show that the DRC is one of the most expensive countries in the world where to establish a business (Lamb, 2011). Significant structural and process barriers in the form of poor governance, multiple informal and formal levies, difficulties in securing loans, and widespread corruption translate into high start-up costs and a formidable bureaucracy that prevents the average DRC resident from establishing and maintaining not only a formal sector business but also from gaining entry into other low-level occupations. When asked why civilian traders and growers entered into the cannabis trade versus other profitable or domestic trades such as the mineral economy, the remote location of minerals featured as a major deterrent but equally important was the lack of start-up capital necessary to dig minerals. As one informant described, starting capital was not the only financial consideration. "It requires someone who knows minerals, much money to go with and another amount to leave to one's wife so that when you spend three months without sending anything, she should not bother you".

Preference for engaging in cannabis production in particular, over a host of potential informal economies and namely markets of other agricultural commodities, depends upon the ecology of the plant as much as the socio-political context in which the trade operates. Cannabis, a robust plant that is easy to grow, requires little labor outside of harvesting and drying, can yield more than one harvest per year, and can be harvested as early as six months from sowing, thus providing farmers an ecologically efficient as well as an economically effective crop that "even in spite of law enforcement problems [...]is a miracle solution for peasants" (Labrousse, 2014).

\section{Congo's Green Gold}

Depending on the level of engagement the range of profits that can be realized at an individual level are quite varied. Few growers, for example, gain much benefit from the trade beyond a household subsistence level earning roughly \$200-\$1000USD per year expressed by informants as enough to meet the "elementary needs" of "feeding my children, buying clothes for them, paying for their studies" and the occasional purchase of livestock such as goats and cows, or having some cash "when your kid is sick you can buy medicine". The greatest profits accrue to traders, particularly crossborder traders, those linked to wealthier or foreign buyers (including international NGO staff and UN affiliates who purchase the drug at a premium price), and higher ranked soldiers in the Congolese army. One military trader, in explaining why a fellow FARDC member was more successful than he, which allowed his friend to purchase two 
motorcycles and provided the capital to start a small shop in the city, noted, "as a captain commander...he has a higher ranking than me". If one can manage the dangers of crossing into Burundi, selling directly to outside markets can bring in as much as three times more income, then it is no wonder that an active trans-border trade exists. As a recent UNODC report (2011, p. 42) notes, under such lucrative circumstances, "onward trafficking seems a rational choice".

The extent to which individuals are able to profit from the trade is further shaped by the region's insecurity. As most cultivators of cannabis harvest their crop at the same climatic period, following the end of the wet seasons (between September and May), farmers unintentionally end up flooding the marijuana market with their product at the same time during the months of June, July and August. As a result, prices for marijuana are cheapest during this period and subsequently rise the further from the day of harvest until the next harvest period. At first glance this might appear to be the result of local enviro-climatic conditions. However, the key to understanding why farmers and traders sell their marijuana in the marketplace at the same time requires asking not when marijuana is largely produced (an enviro-climatic condition) but why cannabis is put on the market when it is (a socio-political condition). Because cannabis is not a perishable product, once dried, it can be stored up to six months with little reduction in potency. Farmers often acknowledged the benefit that selling during the dry season would provide but felt constrained by a number of factors preventing them from waiting to sell. Variations of the response, poverty, presented the major factor influencing farmers to sell quickly after harvest but also fear being caught with sacks of marijuana at home was also noted as an additional condition that prompted farmers to quickly sell. Thus concerns over illegal product seizure and arrest presented a key obstacle for gaining better profits as the need to get cash quickly forced farmers to harvest when the cannabis was not yet ripe (and thus would fetch a lower price on the market), to sell when the market already had a ready supply of the drug, and to sell cheaply to the initial buyer. As one trader explained, "I do not always sell my hemp for the same price due to the fact that the price varies depending on the quantity of hemp that is in the market and also on the security in the area. If there is a high level of security in the area, the hemp sale price goes down, for buyers are buying by not being sure of achieving it all during the retail sale". Even for rural households where accumulation is limited, however, the impact of this illicit trade for individual and household welfare should not be underestimated.

The implications of the trade for improving the material development of rural households is particularly evident during transactions that involve the exchange of material goods in lieu of cash payments for supplies of cannabis. In an environment of poor infrastructure, road networks that become impassable for months out of the year, and the general insecurity of travel in the region, these exchanges are one way that isolated communities get access to a range of subsistence goods, as well as manufactured and luxury items. Items exchanged range widely but common items mentioned include; raincoats, coats, phones, clothes, boots, beer, soft drinks, small fish, mboga (vegetables but also a general term for anything used to garnish the staple of cassava flour), radios, salt, soap, flashlights, plates, iron sheeting, and plastic sheeting. As one grower from Mubaka noted, "those who come from the city and come to buy [cannabis] sometimes bring other items [to exchange] besides money. So sometimes I make little money but I never miss [getting] trousers or food". Some growers even stated a preference for receiving goods over cash payments while several informants 
noted making special requests to traders to bring specific goods on occasion. One informant, for example, related how he exchanged his sacks of cannabis for solar panels - which he uses to generate electricity and subsequently runs one of the few sources of television in the high plateau west of Bukavu.

Far from serving solely as a compensation crop or a 'cushion' during periods of instability or due to a breakdown in wider structural factors, cannabis holds a much more substantial position even within a regulated rural economy. Notably, cannabis fuels the licit economy through invested surplus and through a barter system that brings a level of development to marginalised rural areas and provides the means to maintain social norms and order (including accessing the funds necessary to get married and build a home). The profits earned from the cannabis trade are invested in the future (school fees; dowry; small business start-up), asset creation (livestock; property; infrastructure), as well as present household needs (clothing; household goods; food). That the benefits of the trade serve a wide and diverse range of actors in the region further testifies to its far-reaching impact.

\section{Women at Work}

While armed groups and FARDC members of various ranks - ranging from top end officials to the rank and file of the unranked soldiers - are involved in the trade, an equally if not more diverse range of civilian actors - representing differences in gender, ethnic group, socio-economic class, age, marriage status, origin, occupation, even physical capability - also trade. The inclusion of women is particularly noteworthy. As similarly noted in recent work (see for example Vogel and Musamba, 2017; Perks et al., 2018) examining women's roles and male identification of female spaces in mining communities, women occupy positions and spaces in the production and trade of marijuana in various ways as transporters, traders, and less so as assistants in the planting and weeding stages of cultivation. Some male informants actually seek the assistance of their wives for transporting marijuana as women are seen as being less likely to be arrested, while one trader explains why he chooses to sell alongside his wife, because, "[security forces] cannot arrest both the husband and the wife at once". Regardless of the veracity of that claim, women's main occupation within the cannabis economy is as a trader. In neighboring Rwanda, for example, Emmanual Ngondo, director of Anti-Narcotics at Rwandan National Police, states that women make up the largest percentage of traders trafficking the drugs (Kaitesi, 2012). While women account for a large percentage of the sellers in South and North Kivu as well, many of these women are FARDC soldier's wives (Anon., 2014), a fact that is also noted by the United Nations Group of Experts on the Congo (2011). Soldiers' wives interviewed for this study cast their participation against a backdrop of the low monthly salaries that sometimes arrives each month but which more often does not (see also Eriksson-Baas and Stern, 2010). Thus, with their husband's permission (and frequently also with their encouragement and assistance) wives enter the trade in order to supplement their husband's meagre wages. While women not affiliated with the FARDC also trade, they make up a much smaller percentage as FARDC wives hold a competitive advantage over civilian women through their very association as FARDC wives. Yet while this affiliation presents a fair level of protection, it is certainly one that is not guaranteed (see for example Kimbale, 2013). 
As Cuvelier (2011) notes in his look at businesswomen in Katanga, trading activities in general serve to provide women greater financial autonomy and to gain a better bargaining position vis-à-vis their husbands. But even these femmes d'affaires often rely on start-up money from their husband's or parents. This explicit bias against female participation in business was formalized in the country's legal framework that disallowed married women from getting a job, starting a business, securing a loan, signing a contract or initiating legal proceedings in the DRC without permission of their husbands (Mbambi and Faray-Kele, 2010) ${ }^{10}$. In the absence of marital and familial support systems, the cannabis trade, which requires less start-up capital than traditional market trades, provides a financially suitable alternative for other marginalized groups who do not benefit from the security that marriage provides. Prostitutes, widows, and handicapped women are also known to benefit from the trade's inclusive nature. While prostitutes (who have FARDC officials as clients) and widows of former FARDC officers, like their counterpart FARDC wives, may also gain some competitive advantage over civilian women, these social networks are often unpredictable and can change quickly, particular for widowed wives whose advantage quickly deteriorates after their husband's death.

The inclusion of FARDC wives as well as a broader category of civilian women demonstrates that far from the traffic being the purview of doped-up youth gangs, petty criminals, warlords, or corrupt officials, a substantial percentage of the trade is made up by everyday citizens, many of whom rely on the trade to meet basic requirements not being met at the household (through other means) or national level. In particular it provides an alternative source of income to social groups who otherwise are excluded from other traditional licit sources of income. In addition to widows and prostitutes (of soldiers or otherwise), the trade also provides opportunities to the physically handicapped whose abnormalities prevent them from entering into more traditional but physically demanding occupations such as artisanal mining, agriculture, and even legal market trading that nevertheless still requires mobility and strength. While some traders I met attributed their handicaps to the war, these were often demobilized FARDC fighters who had sustained incapacitating leg injuries. Much more common were men and women whose abnormalities were the result of congenital defects, childhood disease, or later adulthood infections that were never properly treated. One popular trader in Uvira territory, for example, revealed how her entry into the trade was partially the result of a severe rounded back protuberance typical of kyphosis that hindered her ability to access other opportunities including the security of marriage.

Physical disabilities, not only serve as a factor shaping entry into the trade but as several informants noted, the same qualities that present a hindrance to participation in conventional trades, can prove to be a beneficial asset in the illegal trade. Asked about his entry into the trade, a trader points to his physical disability, "It's been about eighteen years since I started trading [marijuana]...I had decided to start growing it when I lost all my fingers due to disease. There was no way for me to work anymore. Thus, I got involved in this trade". Describing how he has managed to avoid arrest during his time as a trader, he again draws on his disability as an important factor, "When the soldiers come to realize that I am fingerless; they decided not to arrest me for this is the only way through which I can get money for my survival". 


\section{Navigating Risk}

Just as the criminalization of the plant has shaped the demographics of those who choose to become involved in the trade, their ability to circumvent the dangers of doing business within this illicit economy depends partly on their ability to subscribe to a new set of growing and selling strategies. In particular, success in the trade relies on the ability of individual growers and sellers "hiding themselves" - a consideration that begins with the location of one's marijuana field. If one were to map the regional location of cannabis farms, some patterns could easily be identified. In particular, most growing areas are geographically concentrated in the more isolated regions of South and North Kivu, such as the Moyens and Hauts Plateaux, those that are further from roads as well as urban centers. Other patterns might be harder to discern without additional information. Some growing areas, for example, benefit for being in close proximity to mining areas, yet still far from the provincial capitals, such as the areas around the mining center of Masisi Town. Even less obvious are the locations of individual marijuana plots even if specific villages, and even exact household locations have been determined precisely because individual hemp fields are often located far from grower's households and separate from the agricultural fields used to grow other crops. Despite the plants ability to grow well with other crops, farmers often forego intercropping cannabis with other household crops. As one farmer explains, "I do not mix [cannabis with my food crops] because I often fear maybe the soldiers can identify my field and will uproot everything in the field". Thus the separation of food crops from cannabis ensures that, even in the event of discovery, no subsistence plants go the way of seized cannabis harvests. Fear of having one's marijuana plot discovered, however, is not limited to being discovered by security agents. As another farmer explains, "I do not mix [cannabis] with any other crop because many people will see that hemp if I mix it with food crops, which could compromise its production, for many people will come to know [that I am growing hemp], for they will see it because the food crop fields we usually cultivate are in open spaces where everybody passes. Whereas hemp, it is always cultivated in hidden places and that is the difference". For the same reason, farms of cannabis plants are usually not weeded despite its benefit for increasing plant development and production, "since weeding clears the field, making it such that any one from far away can identify that it is hemp [that you are growing]". Fields of hemp are however often intermixed with other [limited value] weedy plants. As noted by another grower, "when marijuana grows with other plants that we do not use in our lives, it will be difficult for most people to determine what is growing inside the field from far away". The fear of being discovered shapes not only where cannabis farms are located and how the plant is cultivated within the local environment, it also shapes how labor in the production of cannabis is structured.

Unlike the production of food crops that draws on multiple field hands in the various stages of planting, weeding, and harvesting, labor in the production of the cannabis plant is often done by a single individual - that of the cannabis owner himself. As one informant noted, "the land cultivation, the acquisition of seed, the harvest time and the sale period, no one from my family helps me do it". Another farmer explains, "the harvest time does not involve other people as we usually do in other crops since [those laboring on your marijuana farm] may spread the news that you are a hemp grower and besides many will not agree to come to help you for they know that to do so is to expose themselves to danger". Thus, cultivators often keep their farms secret even 
from other villagers and neighbors, whom several respondents noted might retaliate for past transgression or to settle an unresolved conflict. As articulated by one grower, "no one knows the place [where I grow marijuana] except myself... they do not know my field because I do not want them to know it...if they come to know the [location of the] field they might plot with security members to arrest me, for one cannot trust anyone in this world". While the involvement of their wives in the production of marijuana was often linked to claims of their "fearfulness" or as previously noted, their religious devotion, for some growers, not involving their wives represented a similar strategy for remaining safe. "[Wives] they do not want to be arrested. But they are the first to ask for the money you have received [from the sale of marijuana]. And if you want to get arrested easily, please ask your wife to help you in that business for the day you quarrel with them, hemp is the only thing she will be claiming to be in your head that troubles you, and from there everybody will know that you are a hemp grower or smoker".

Strategies for staying safe also shape how and where people store their harvest, when and how transport of cannabis to the market is accomplished, and to whom and in what quantity cannabis is grown and sold. Most respondents, for example, cited some variation of "hiding" or "burying" their sacks of harvested cannabis prior to selling them - an activity that usually occurs in the fields rather than in the household and remains there until a destination for their hemp is determined. As a similar precaution, buyers are usually not permitted to arrive directly at growers' fields but to an agreed upon meeting place for the exchange. During transportation, marijuana is often hidden through packaging that involves layering either clothing or charcoal that "[are] put on the bottom and [sic] others on the top of the sack so [the marijuana can]not to be easily identified". Some traders also spray their sacks with perfume in order to mask the strong smell that marijuana typically emits. That the smell much more so than the plants visibility is repeatedly noted as a major factor within the narratives of those who have been caught, confirms the significance of this strategy.

Remaining hidden necessitates strategies that reduce visibility but also tactics that reduce exposure. The desire on the part of both growers and traders to reduce exposure shapes the quantity that growers produce and the quantity by which traders sell by. "The insecurity", one grower lamented, "is the main element that prevents us from not growing more. For the more you grow the more it is dangerous to you because you will have to sell it to different places and that is how it will become dangerous to you". A trader similarly relates, "I do not want to sell by boules ${ }^{11}$ because to do so is to expose oneself to multiple risks". Most marijuana thus tends to be transported and sold from the site of production in larger qualities of 30,50, or $100 \mathrm{~kg}$ sacks in order to reduce the number of buyers and thus minimize the risk to growers of exposure by others. In addition, the fear of exposure strongly influences sellers' decisions of whom they will or will not trade with. Some traders, for example, refuse to trade with soldiers whom they see as capable of "plot[ing] against me". As one seller explained, "I sell it to civilians only because I do not want to put myself at risk. Soldiers are always complicated and do not have friends. When he is moneyless, he is your friend but when he has money he becomes otherwise". Others spoke of the need to be cautious to any potential new buyer particularly in light of the well-known practice of security agents pretending to be buyers. The concern of exposure also shapes the strategies people use to transport marijuana to their intended destination/buyer. Some, for example, choose 
to travel during nighttime as they argue it presents a cover with which to more safely move by, whiles others do not travel at night for fear of meeting with 'evil spirits'.

Strategies for staying safe and reducing risk of exposure and potentially of arrest, are thus multiple and varied. Yet while informants lamented the dangers encountered though their engagement in the cannabis economy, most informants recognized that within the trade a certain level of risk was to be expected. As one big trader noted, "When you start [any type of] work you also must accept its risks. It is like someone who loves a woman and wants her to be his wife but does not want her family-in-law. Or you want to be a fisherman but ignore the risks of drowning, or capsizing". For most traders then, a key factor for being able to successfully navigate the multiple dangers and risks in the trade was often expressed as individual character traits such as mafu $m a f u^{12}$ (fearlessness) and ndabitwaza ${ }^{13}$ (without worry). Even amongst those who claimed to have the "heart of a lion" however, one risk in particular presented itself as a formidable and the most significant challenge across all respondents' stories. As one informant offered in summary, "there is much risk when going to sell because you do a movement. Harvesting, growing or weeding holds some risk but not as much as bringing it to market".

\section{Negotiating Danger}

Speaking on the role of the tobacco plant in Southern Lebanon, which exhibits similar ecologically and economically beneficial qualities, Khayatt (2012, p. 477) privileges the plant as a 'war-i-time success', a distinction that can similarly be applied to the role of cannabis in the DRC's current landscape of 'no war no peace'. Its ecology (a hardy plant; easy to grow; amenable to interplanting; and relatively fast growing) means that it is attuned to the spatio-temporal parameters of Congo's warscape (both for victims as a compensation crop, as a source of food security when other crops such as the staple cassava take longer to cultivate, and also to armed groups who can easily grow it. At the same time, the same characteristics that factor into its success to suit the Congo's warscape and in light of its illegality- its disparate and distant character (being diffuse, and being remote) in order to be hidden - it requires a complex set of social relations to get from grower to trader to consumer which in turn means that such relations consequently shape the very socio-temporal parameter of the trade and the landscape of violence itself. For example, the same qualities that promote the armed group FDLR's ability to engage in production, notably geographic isolation, also stand as barriers to the group's ability to participate in the commercialization end of the drug's trade, necessitating that the group collaborate with members of the military and other armed groups against whom they are said to be fighting. For citizens involved in the trade, it is in "navigating the war terrain" (Vigh, 2016) that the greatest insecurity associated with the trade lies.

The engagement in an illegal trade in an area of weak state oversight and control means that traders must navigate the physical crossing of a landscape of insecurity as well as a complex socio-political landscape of insecurity. When asked about the dangers associated with the trade, citizens unanimously cited that the greatest risk faced by growers and traders was often met 'along the way'. These largely random and unpredictable encounters occur during the transport phase when traders and growers are moving sacks of marijuana from the area of cultivation to its first location of sale 
and are met by individual members of armed militias or FARDC soldiers literally 'along the way'. While these meetings are commonly seen as being 'random' and occurring 'by chance', (as opposed to 'legal' checkpoints patrolled and enforced by the FARDC) many of the encounters with individual army members, in particular, occur where military checkpoints or bases have been established nearby. During such encounters, transporters may be arrested, have their goods seized, or be asked to pay a fine in lieu of an arrest. In some cases, multiple scenarios happen simultaneously, for example, when military members and individuals from armed group walk away with the sacks of marijuana along with any cash being carried on the individual's person. Even in instances of arrest, however, after paying a settlement for their release, few traders were ever actually sent on further to the regional prison. While such episodes appear like nothing more than outright cases of banditry and pillage, most interactions do not end leaving transporters in absolute destitution for the very reason that such encounters are mirrors of social relations as much as they are influenced by the search for personal profit.

The ability of each actor to secure access to and successfully compete in the cannabis trade, is rooted in their economic and political capacity to manipulate varying personal relations and networks. Familial, customary, friendly and ethnic relations were all cited as necessary precursors to entering potential areas to acquire tradable quantities of cannabis. Strong and extensive social networks are so valued in the trade that when participants were asked to list the qualities that define a successful trader, two of the six characteristics provided spoke directly to one's social networks while an additional two were closely linked to strong social endowments. According to respondents, the success of a trader depends on (1) their recognition by others as a trader; (2) their fearlessness (3) their experience, intelligence, and knowledge of the trade; (4) the quantity of cannabis traded; (5) their connections to FARDC; and (6) their ability to move across national borders to access more profitable international markets. Thus to be a successful cannabis trader in the Congo requires more than attention to numerical accounts of goods sold or profits gained but rests on the possession of strong social capital to gain access to a wide clientele and to build the connections necessary to minimize the risks of engaging in an illicit trade. Ironically then, success in the business of one of Congo's most notorious shadow economy requires for traders not to be hidden, but rather "to be known".

To clarify however, this requires that traders are known by the appropriate social networks and individuals and that this act of 'knowing' is couched in terms of reciprocity. Traders intentionally develop 'friendships' by gifting small quantities of cannabis and sometimes other goods such as beer and/or cash to individual armed group members which is key to securing safe passage and avoid arrest. As a village chief and grower explains, "I stay safe in the area because I often make myself a friend of soldiers and commanders. Most of the time, when there is a soldier who is in my area, he first of all must come to show himself up to me as the chief, after I ask him if he also smokes cigarettes. If he accepts I ask him then what kind of cigarette, even hemp? If he says yes, then I bring it to him for free, I do this same activity a second and third time. From there, he becomes my friend. A soldier or a security member arrests someone depending on your way of expressing or introducing yourself to them. In addition, you must be fast-giving as in providing $3000 \mathrm{FC}$ or $5000 \mathrm{FC}^{14}$ to give him as transport. I often do so many times. Afterwards I tell him about my hemp activity and the reason I am doing it. That is why I never get arrested". Conversations with FARDC 
personnel present further evidence of the importance of these connections. As one Commander related, "I remember when I was based in Kabinda territory... There had come a [big] grower to our camp to see our chief. The guy brought 24 bottles of beer with a goat to tell our chief that he grows hemp thus we should protect him. The chief agreed but told him to be giving something like a cigarette to his soldiers so that they might not arrest him when the chief is away".

These connections are not only critical for civilians trading within a militarized landscape, but are crucial for army traders as well. As one FARDC informant noted, "our safety in the trade depends on how we are living or staying with our chiefs". Success in the trade is consequently seen as being built from and reliant on a positive relational outcome, one that is determined as much by cultural linkages, such as through a common ethnicity, as through a social one. "If some soldiers are not involved or successful in the trade it is because of how they behave when they are trading.... [when] they are too troublesome and impolite towards the authorities," one FARDC trader remarked, "In that way, you cannot be successful in its trade for every time you will have problems with your commanders for you are rude". Being "courteous", illustrating displays of "humility" and not being "haughty" or "impolite" were identified as important traits to show among both civilian and military traders. Behavioral attributes featured as consequential factors not only in determining whether one would be able to garner the support of a high ranking army official but also helped determine the extent to which one's profits would be seized during a random arrest. "For instance, when you arrest someone who has a lot hemp but he humiliates himself to you and asks for forgiveness, you will reduce the cost of charging him from 80USD to 20USD... But if you arrest a trader or grower and he does not humiliate himself to you, you will ravish the whole quantity of hemp and in addition charge him some money according to the quantity of hemp". Some FARDC respondents suggested such placates by civilian traders were more important than their drawing on other cultural ties. "Sometimes, you will come across [a civilian trader] saying that he is a family member to a certain chief or he begins speaking in Lingala to show you that you cannot intimidate him. For such people, we do not tolerate them. We ravish the hemp and ask him to call his chief he boasts for".

Even when traders are able to connect to appropriate social networks however, what constitutes the appropriate social networks changes according to different social environments, which are not static. Few traders, for example, are able to access the inner circle of top ranking FARDC officials but most admit to knowing a captain or a lieutenant as well as several rank and file army members that they collaborate with. These collaborations, particularly among the rank and file, are often short lived as groups are frequently rotated after every six months requiring that traders continuously rebuild new 'friendships'. Some traders rely on connections to members of rebel groups as well. Growers in the Ruzizi Plain for example have in the past called on the FDLR whom they frequently traded with to provide them armed escorts along part of their journey from the rural areas to shelter them from random stops by FARDC personnel. This however has changed as recent military movements against the group pushing them further afield from these communities and as some informant's argued, upsetting the previous balance established in the area making current interactions with the group increasingly dangerous. Still others draw on government administrators for protection while almost all rely on community leaders for support. Even within official anti-drug networks, hard lines are rarely ever drawn and 
negotiation remains an influential tool for traders. Labeled elsewhere as 'institutional connectedness' (Claessens et al., 2013, p. 14), these inter-personal relations then are critical to determining individuals' success in navigating through what is a complex and plural socio-political landscape. The ability to connect to these networks, however is highly unequal and often reinforces existing social inequities among the local population. For example, big traders can readily purchase future reciprocity, through their ability to pay a more substantial "présentation des civilités"15 while other big traders do so by means of their personal networks to higher ranking officials and administrative staff. One such trader reflected on how his own success in the trade was largely attributed to his connections to important regional actors including an aunt who served as the chief of Uvira city. For traders with less capital to expend towards such 'gifts of reciprocity,' or are socially marginalized, their ability to access these same networks is severely restricted and as a result so is their ability to circumvent arrest and the severe fines that often accompany those arrests. As one small trader recounted, "the laws exist to us, people of the lower class, who have no defenders". Further explained by another small trader, "Every person without distinction who is involved in the trade is vulnerable of pursuit since there is no exception unless you have an authority to defend you...". Thus while economic concerns may provide the main motivation for entering the trade, to understand the mechanisms shaping the outcomes of the trade, its opportunities, and its restraints, requires taking a sociopolitical turn.

\section{Conclusion: Revisiting the Curse of the Congo}

Responding to the network of informal and formal systems that emerged within Somalia's wider political environment of armed conflict and criminality, Ken Menkhaus (2004, p. 163) once argued, "that those systems are all but invisible to most external actors does not make them less present or significant". The place of marijuana in the Congo and in particular the informal networks and systems that are drawn on and reworked therein, draws similar parallels. The Congolese trade in cannabis sativa remains, for the most part, a hidden economy. Just as users of the herb continue to be stigmatized, the trade in marijuana still maintains a "fringe" (see Verbeke and Corin, 1976 , p. 169') position within academic debates on natural resource conflicts, informal economies, and livelihood security. Similarly, it has yet to be able to garner the attention of most international actors working in the region such that when asked about the cannabis economy, a UN political affairs officer in Fizi once emphatically stated that "there is no such trade".

As this article has demonstrated, the presence and significance of the herb to the lives of Congolese and of its economy for the livelihood of Congolese presents a critical alternative perspective. Rather, Congo's cannabis economy is in fact loaded with cultural and economic significance. It reflects a powerful political history of Congolese resistance. It further serves as a key site for contemporary understanding of how local people navigate, survive, and subvert everyday forms of insecurity and violence in an enduring and fractured landscape of armed groups and gapping inequalities. Yet its importance to Congolese people and society has been overshadowed by outside narratives that continues to place the trade and consumption of cannabis alongside instances of corruption, crime, greed, abuse, and rape, rather than food security, 
livelihoods, reciprocity, and cost-effective (alternative) healthcare. As a result, most policies on the cannabis economy continue to focus on the criminal aspects of the drug, which almost inevitably reduces it to simply a vehicle for violence, underdevelopment and regional instability. In this way, discussions of the trade in marijuana, if and when they happen, do not look very different from when Melville William Hilton-Simpson, writing his travelogue entitled "Land and Peoples of the Kasai" in 1911, singled out hemp smoking as "the curse" of the Batetela (p. 256). Rather perhaps the real curse of Congo's cannabis trade is that despite mounting evidence to the contrary regarding the causal role of marijuana and violence in the region, despite a growing recognition of marijuana's role as a legitimate (if not legal) and significant livelihood strategy for rural households across the continent, despite evidence that the real dangers associated with the trade arguably result not in spite of its prohibition but precisely because of it, outside observers continue to reject empirical evidence in favor of dangerous stories (Autesserre, 2012) and toxic discourses (Laudati and Mertens, 2019). Returning to the photographed farmer that began this paper we can thus understand the curse of the cannabis trade another way. Perhaps the real 'curse', that the farmer likely already recognizes and subsequently sought to cure through the staging of the photograph as he did, was that we fail to see even when those hidden economies are exposed in plain sight.

Menkhaus.K., 2004. Vicious circles and the security development nexus in Somalia. Conflict, Security \& Development, vol. 4, n² 2, p. 149-165.

\section{BIBLIOGRAPHY}

Abraham I., Van Schendel W., 2005. Introduction: The making of illicitness. In Van Schendel W., Abraham I., (eds), Illicit Flows and Criminal Things: States, Borders, and the Other Side of Globalization. Bloomington: Indiana University Press, p. 1-37.

Acker F. van, 2005. Where did all the land go? Enclosure and social struggle in Kivu (DR Congo). Review of African Political Economy, $\mathrm{n}^{\circ}$ 103, p. 79-98.

Anon., 2014. Rwanda: FDLR Generating U.S. \$71 Million from Businesses with Wives of DRC Officers. News of Rwanda, September 28.

Anon., 2018. Ituri: 10 sacs de chanvres et un lot très important de liqueurs en sachets incinérés. [Online] https://congoprofond.net/rdc-beni-8-sacs-de-chanvre-et-des-boissons-fortementalcoolisees-prohibees-incineres/

Autesserre S., 2012. Dangerous Tales: Dominant Narratives on the Congo and Their Unintended Consequences. African Affairs, vol. 111, n 443, p. 202-22.

Baerts M., Lehmann, J., 1989. Guérisseurs et plantes médicinales de la région des crêtes Zaïre-Nil au Burundi. Tervuren, Musée royal de l'Afrique Centrale, $214 \mathrm{p}$.

Baerts M., Lehmann, J., 1991. Plantes médicinales vétérinaires de la région des crêtes Zaïre-Nil au Burundi. Tervuren, Musée royal de l'Afrique Centrale, 133 p. 
Balagizi I., Cihyoka A., Mapatano S., 2005. Lexique et recueil des quelques pratiques en ethnopharmacopée agro-vétérinaire au Kivu. Plateforme Diobass au Kivu [En ligne].

Bernault F., 2007. The Shadow of Rule: Colonial Power and Modern Punishment in Africa. In Dikötter F., Brown I., (eds.), Cultures of Confinement: A History of the Prison in Africa, Asia and Latin America. London, Hurst and Company, p. 55-94.

Bloomer J., 2009. Using a political ecology framework to examine extra-legal livelihood strategies: a Lesotho-based case study of cultivation of and trade in cannabis. Journal of Political Ecology, vol. 16, $\mathrm{n}^{\circ}$ 1, p. 49-69.

Bokdam J., Droogers A.F., 1975. Contribution à l'étude ethnobotanique des Wagenia de Kisangani, Zaïre. Wageningen, H. Veenman \& Zonen B. V., 74 p.

Byavu N., Henrard C., Dubois M., Malaisse F., 2000. Phytothérapie traditionnelle des bovins dans les élevages de la plaine de la Rusizi. Biotechnol. Agron. Soc. Environ., vol. 4, n³ 3, p. 135-156.

CIA, 2013. The World Factbook 2013-14. Washington DC, Central Intelligence Agency. [En ligne] https://www.cia.gov/library/publications/download/download-2013/index.html

Claessens K., Mudinga E., Ansoms A., 2013. Land Grabbing by Local Elites in the Territory of Kalehe, South Kivu, Eastern DRC. Paper prepared for presentation at the Annual World Bank Conference on Land and Poverty, The World Bank, Washington DC, April 8-11.

Cuvelier J., 2011. Men, Mines and Masculinities: The Lives and Practices of Artisanal Miners in Lwambo (Katanga province, DR Congo). University of Leuven, PhD Thesis, 387 p. https://biblio.ugent.be/ publication/1863372/file/1863421

Disengomoka I., Delaveau P., 1983. Medicinal plants used for child's respiratory diseases in Zaire. Journal of Ethnopharmacology, vol. 8, n 3, p. 257-263.

Dembour M., 2000. Recalling the Belgian Congo. New York, Berghahn Books, 86 p.

Dowiya N.B., Rweyemamu C.L., Maerere A.P., 2009. Banana (Musa spp. Colla) cropping systems, production constraints and cultivar preferences in eastern Democratic Republic of Congo. Journal of Animal and Plant Sciences, vol. 4, n 2, p. 341-356.

Duvall C., 2017. Cannabis and Tobacco in Precolonial and Colonial Africa. Oxford, Oxford University Press, 38 p. [En ligne] DOI: 10.1093/acrefore/9780190277734.013.44

Eriksson-Baas M., Stern M., 2010. The Complexity of Violence: A Critical Analysis of Sexual Violence in the Democratic Republic of Congo (DRC). Stockholm, Sida and the Nordic Africa Institute, 70 p. [En ligne] http://www.diva-portal.org/smash/get/diva2:319527/FULLTEXT02

Fabian J., 2000. Out of our Minds: Reason and Madness in the Exploration of Central Africa. Berkeley, University of California Press, 335 p.

Hewlett B., 1977. Notes on the Mbuti and Aka pygmies of Central Africa. Master's thesis, California State University.

Hunt N.R., 2016. A Nervous State: Violence, Remedies, and Reverie in Colonial Congo. Durham and London, Duke University Press, 376 p.

ICRC, 2010. Democratic Republic of the Congo: economic support for isolated residents of South Kivu. ICRC Feature, February 10.

INCB, 2012. Report of the International Narcotics Control Board for 2012. New York, United Nations. [Online] https://www.incb.org/incb/fr/publications/annual-reports/annualreport-2012.html 
INL, 2011. International Narcotics Control Strategy Report: Volume I. Drug and Chemical Control. United States Department of State Bureau for International Narcotics and Law Enforcement Affairs, March. [Online] https://www.state.gov/j/inl/rls/nrcrpt/2011/vol1/index.htm

Kaitesi M., 2012. Most Drug Dealers Are Women. New Times (Rwanda), November 18.

Kalanda K., Bolamba K., 1994. Contribution à la connaissance des plantes médicinales du Haut Zaïre. Les plantes utilisées contre les maladies de la peau à Kisangani. Revue de Médicine et de Pharmacie, Africa, vol. 8, n², p. 179-188.

Kandala N.B., Madungu T.P., Emina J.B.O., Nzita K.P.D., Cappuccio F.P., 2011. Malnutrition among children under the age of five in the Democratic Republic of Congo (DRC): Does geographic location matter? BMC Public Health [Online], vol. 11, $\mathrm{n}^{\circ} 261,15$ p. https:// bmcpublichealth.biomedcentral.com/track/pdf/10.1186/1471-2458-11-261

Kasonia K, Anay M, Gustin P., Plume C., 1993. Ethnobotanique du traitement de l'asthme au Kivu (Zaïre). Belgian Journal of Botany, vol. 126, $\mathrm{n}^{\circ}$ 2, p. 20-28.

Kimbale R., 2013. RDC: Plus de vingt militaires FARDC et leurs femmes arrêtés à Buni, Radio Canal Révélation (Bunia), June 6.

Khayatt A., 2008. The Arab Anti-Corruption Organization. Contemporary Arab Affairs, $\mathrm{n}^{\circ} 1$, p. 471-477.

Labrousse A., 2014. Sub-Saharan Africa Facing the Challenge of Drugs (Parliament of Canada, undated). [Online] http://www.parl.gc.ca/Content/SEN/Committee/371/ille/presentation/ labrousse1-e.htm

Lamb G., 2011. Assessing the Reintegration of Ex-Combatants in the Context of Instability and Informal Economies: The Cases of the Central African Republic, the Democratic Republic of Congo and South Sudan. Washington DC., World Bank. [Online] https://openknowledge.worldbank.org/handle/ $10986 / 27276$

Laniel L., 2006. Producing Cannabis in Africa South of the Sahara: A Review of OGD Findings in the 1990s. Paper prepared for the International Workshop on Drugs and Alcohol in Africa: Production, Distribution, Consumption \& Control. St Antony's College, University of Oxford, 23rd May.

Laudati A., 2013. Beyond Minerals: Broadening 'economies of violence' in Eastern Democratic Republic of Congo. Review of African Political Economy, vol. 40, n 135, p. 32-50.

Laudati A., 2014. From out of the Shadows: Negotiating Livelihood in Eastern DRC's Cannabis Trade. In Klantschnig G., Carrier N., Ambler C., (eds), Drugs in Africa. Palgrave, p.161-180.

Laudati A., Mertens C., 2019. Rape and Resources: Congo's (Toxic) Discursive Complex. African Studies Review (forthcoming).

Mbambi A.M., Faray-Kele M.C., 2010. Gender Inequality and Social Institutions in the D.R. Congo. Report provided to the Women's International League for Peace and Freedom (WILPF), April-December 2010.

Muengula-Manyi M., Nkongolo K., Bragard C., Tshilenge-Djim P., Winter S., Kalonji-Mbuyi A., 2012. Incidence, Severity and Gravity of Cassava Mosaic Disease in Savannah Agro-Ecological Region of DR-Congo: Analysis of Agro-Environmental Factors. American Journal of Plant Sciences, vol. 3, $\mathrm{n}^{\circ} 4$, p. 512-519.

Mupanda D., 2018. RDC/Beni: 8 sacs de chanvre et des boissons fortement alcoolisées prohibées incinérés. [Online] https://congoprofond.net/rdc-beni-8-sacs-de-chanvre-et-des-boissonsfortement-alcoolisees-prohibees-incineres/ 
Raeymaekers R., 2005. Collapse or Order? Questioning State Collapse in Africa. Conflict Research Group, Working Papers, $\mathrm{n}^{\circ} 1$.

Ragasa S., Ulimwengu J., 2011. Institutional and Capacity Challenges in Agricultural Policy Process: The Case of Democratic Republic of Congo. Washington DC, IFPRI Discussion Paper, 48 p. [Online] http:// www.ifpri.org/publication/institutional-and-capacity-challenges-agricultural-policy-process

Ritchie T., 2012. A Familiar Frontier: The Kennedy Administration in the Congo. Master's Thesis, Brandeis University, 98 p.

Rossi L., Hoerz T., Thouvenot V., Pastore G., Michael M., 2006. Evaluation of health, nutrition and food security programmes in a complex emergency: the case of Congo as an example of a chronic post-conflict situation. Public Health Nutrition, vol. 9, $\mathrm{n}^{\circ}$ 5, p. 551-556.

Roulette C., Hewlett S., 2018. Patterns of Cannabis Use among Congo Basin Hunter-Gatherers. Journal of Ethnobiology, vol. 38, $\mathrm{n}^{\circ}$ 4, p. 517-532.

Roulette C., Kazanji M., Breurec S., Hagen E., 2016. High prevalence of cannabis use among Aka foragers of the Congo Basin and its possible relationship to helminthiasis. American Journal of Human Biology, vol. 28, n 1, p. 5-15.

Sagan C., 1977. The Dragons of Eden, Speculations on the Origin of Human Intelligence. New York, Ballantine Books.

Seay L., 2012. What's Wrong with Dodd-Frank 1502? Conflict Minerals, Civilian Livelihoods, and the Unintended Consequences of Western Advocacy. Center for Global Development, Working Paper $n^{\circ} 284$.

Suckling C., 2016. Cultivating hierarchy: the reproduction of structural advantage in Sierre Leone's cannabis economy. Review of African Political Economy, vol. 43, n 148, p. 206-226.

Timbs J., 1890. Curiosities of Science: 2d Ser. A Book for Old and Young. London, Kent and Co.

Ulimwengu J., Funes J., Headey D., You L., 2009. Paving the way for development? The impact of transport infrastructure on agricultural production and poverty reduction in the Democratic Republic of Congo. Washington DC, IFPRI, IFPRI Discussion Paper.

United Nations Office on Drugs and Crime, 2011. World Drug Report 2011. Vienna, UNODC.

United Nations Security Council, 2011. Final Report of the Group of Experts on the DRC. December 2.

Walangululu M.J., Cizungu L.N., Birindwa R.D., Bashagaluke B.J., Zirhahwakuhingwa M.W., Matabaro M., 2011. Integrated soil fertility management in South Kivu province, Democratic Republic of Congo. African Crop Science Conference Proceedings, vol. 10, p. 161-164.

Williams S., Warf B., 2016. Drugs, law, people, place and the state: ongoing regulation, resistance and change. Space and Polity, vol. 20, $n^{\circ} 1$, p. 1-9.

World Bank. 2018. Democratic Republic of the Congo - Small Development and Growth Project. World Bank Report No. PAD2448, June 7.

Verbeke R., Corin E., 1976. The Use of Indian Hemp in Zaire: A Formulation of Hypotheses on the Basis of an Inquiry Using a Written Questionnaire. The British Journal of Addiction to Alcohol and Other Drugs, vol. 71, n² 2, p. 167-174.

Vigh H., 2006. Navigating terrains of war. Youth and soldering in Guinea-Bissau. Oxford, New York, Berghahn Books, 258 p.

Vlassenroot K., Ntububa S., Raeymaekers T., 2003. Food security responses to the protracted crisis context of the Democratic Republic of the Congo. Paper presented at International Workshop 
on Food Security in Complex Emergencies: Building policy frameworks to address longer-term programming in complex emergencies, 23-25 September, Tivoli, Italy.

York G., 2012. Young and Dying: The Scandal of Artisanal Mining. The Globe and Mail, August 18.

\section{NOTES}

1. Shamba is a Swahili word used by Congolese to refer to a plot of land where one farms, commonly translated as a 'farm' in English vernacular. Rather than a single plot of land, however most farming households in the Congo tend to have multiple shambas (i.e. plots) that are spatially diverse in order to take advantage of different geographical-ecological zones.

2. This paper uses the shorthand term cannabis, an abbreviation of the botanical name Cannabis sativa. I note here that Congolese actors use varied terms for the plant, reflecting regional language variations both across Europe and North America and within the country of the DRC itself. For the DRC, where English is rarely spoken as French is the official language, the French term chanvre is the term widely understood in the country, and when translated into English, hemp is the term widely used. Among locally spoken languages, the Swahili translation, bangi, is widely understood in the Eastern part of the country by different ethnic groups although most languages have their own translations. I use these terms together with marijuana interchangeably throughout the text.

3. All quotes presented of local Congolese, unless otherwise noted, are drawn from the author's fieldwork in the DRC.

4. While this paper does not delve into ongoing debates surrounding the drug's contribution to violent behavior, that an increasing number of states have drawn up plans to if not already officially legalized the drug certainly offers pause to the drug's role as an instigator of violence. That within the DRC, peacekeepers as well as international NGO staff are regular consumers of the same drug blamed for perpetrating violence by armed groups in the region presents cautionary evidence against simplistic causal claims between acts of violence and cannabis consumption.

5. There is some debate about the exact ethnic identity of the original group. Even the origins and translation of the term 'Bene Diamba' has been argued. The scope of these debates are beyond the relevance of this paper however and instead references are cited here to guide the reader to further reading on this topic.

6. Kivubo or Civubo is a disease that affects children usually under the age of one, on his/her anal and genital area, with symptoms that include diarrhea and emaciation.

7. For an argument linking Patrice Lumumba's use of cannabis to his eventual assassination, see Ritchie (2012).

8. It is important to note that while previous writing has suggested that armed groups were able to profit from the production of marijuana - in fact few groups have (and continue) to be able to do so. As one informant noted, growing marijuana "requires peace time to deal with it". Rebel groups, including the national army, are rarely stationed in one place for substantial periods of time and notably for the time that it takes for the marijuana to reach the harvesting stage. This temporal insecurity thus prevents most groups from growing a significant quantity of marijuana (or any other agricultural commodity). Armed group members that do grown then, tend to produce only small amounts close to their encampments 50 enough for personal use and small enough not to incur a great loss in the case of forced evacuation from their base.

9. See for example; Anon., 2018 and Mupanda, 2018 
10. In 2016, reforms made under the Family Code removed many of these legally binding constraints but research suggests that these reforms have largely failed to be implemented in practice (World Bank 2018).

11. Boules, meaning balls in French, refers to the way that the smallest quantity of marijuana about one ounce - are packaged - rolled up as small balls often in newspaper.

12. From the Bafuliro language.

13. From the Bafuliro language.

14. FC stands for the local currency, Franc Congolais. This amount converts to roughly $\$ 1.83 \mathrm{USD}$ and \$3.06USD respectively.

15. Translated directly from French as "presentation of civilities", its use refers to a form of reciprocity payment where the payer can expect, in the case of the cannabis trade, that the payee will advocate on their behalf. These are usually provided to higher ranking officials and administrative staff who have the power to intervene in cases of arrest, or to help facilitate safe passage.

16. One of the earliest (and still few) academic surveys conducted on the use of cannabis in what was then Zaire, the authors grouped results into three associative categories of marijuana users; (1) violence; (2) stardom; and (3) fringe.

\section{INDEX}

Keywords: Narratives surrounding the Democratic Republic of the Congo's rich natural resource base have been largely attentive to the way that resources shape the enduring violence in the region. Current policies regarding Congo's cannabis trade, which advocate for its continued prohibition, exemplify such framings. Drawing on over sixteen months of qualitative fieldwork with those engaged in the production and trade of the drug, this paper presents a direct challenge to the narrative of violence, delinquency, and greed that currently foregrounds most discussions of Congo's cannabis economy. It reframes the cannabis trade as a response to Congo's landscape of insecurity, rather than a symptom of it. It offers evidence of how it is rather the plant's illegality and the extra-legal networks its illegality engenders that are shaping the terms of this dangerous trade. In so doing, this paper seeks to confront how we understand the very terms of risk and insecurity as played out in the day-to-day lives of those who navigate through the hidden economy of Congo's cannabis trade.

\section{AUTHOR}

\section{ANN LAUDATI}

Ann Laudati, alaud@berkeley.edu, is a Visiting Professor and Social Science Research Fellow in the Department of Geography at the University of California, Berkeley. She recently published : - Laudati A., Mertens C., 2019. Rape and Resources: Congo's (Toxic) Discursive Complex. African Studies Review, (à paraître).

- Laudati A., 2016. The Making of a Shadow Economy: Securing Insecurity in Eastern DRC's Cannabis Trade. Review of African Political Economy, vol. 43, n 148, p. 190-205.

- Barclay S. M., Laudati A., 2016. The Changing Face of Chattara: African Migrants, Mobilities, and 
Movements in Barcelona. In Grabowska G. (ed), Movers and Stayers: Sub-Saharan African Migration Decisions and Changing Conditions in the Mediterranean 